\title{
Evaluation of the First Automated Thyroglobulin Assay
}

\author{
Michael Vogeser ${ }^{1}$, Peter Knesewitsch ${ }^{2}$, Karl J acob ${ }^{1}$ and \\ Dietrich Seidel ${ }^{1}$ \\ ${ }^{1}$ Institute of Clinical Chemistry, \\ ${ }^{2}$ Clinic for Nuclear Medicine, \\ Klinikum Grosshadern, Ludwig-Maximilians-Universität \\ Munich, Munich, Germany
}

\begin{abstract}
The aim of this study was to investigate technical and analytical performance of the first automated thyroglobulin (Tg) assay (DPC-Immulite ${ }^{\circledR}$; Diagnostic Products Corporation, Los Angeles, USA). In imprecision studies using several human serum pools ranging from 21 to 58 replicates, a coefficient of variation of 9.0 $\%$ was obtained at a mean $\mathrm{Tg}$ concentration of $\mathbf{0 . 8 4}$ $\mathrm{ng} / \mathrm{ml}$ and of $6.1 \%$ at a Tg concentration of $62.1 \mathrm{ng} / \mathrm{ml}$. In a method comparison with a non-automated assay (BRAHMS LUMltest Tg ${ }^{\circledR}$, BRAHMS, Berlin, Germany) using 383 sera of 303 patients with thyroid carcinoma, regression analysis according to Passing and Bablock yielded in the following equation:
\end{abstract}

$$
\begin{aligned}
& \text { Immulite Tg=1.6x BRAHMS Tg }-0.1 \mathrm{ng} / \mathrm{ml} \\
& \text { (Pearson's r=0.979). }
\end{aligned}
$$

Sera obtained from 59 patients with thyroid carcinoma enabled comparative follow-up studies; in all cases qualitative agreement was found with regard to increase or decrease of serum Tg; in eight cases, however, Tg was detected with the Immulite assay but not with the BRAHMS assay. Further follow-up proved the presence of thyroid tissue in these patients. From these and further methodological data (dilution linearity, interference studies, carry-over study, high-dose hook properties, and short report time) it is concluded that the DPC-Immulite Tg assay meets the requirements of routine diagnostic use.

Key words: Thyroglobulin; Immunoassay; Thyroid carcinoma.

\section{Introduction}

Thyroglobulin $(\mathrm{Tg})$, a heterogeneous iodoglycoprotein with a molecular weight of about $660 \mathrm{kDa}$, is a main constituent of the vesicular thyroid colloid. It is synthesized under regulation of thyrotropin exclusively by the thyroid gland and is the precursor of thyroxine and triiodothyronine. The main indication for determination of serum $\mathrm{Tg}$ is the follow-up of patients with differentiated thyroid carcinoma after thyroablative surgery and radioiodine therapy; measurable and increasing serum Tg concentrations are an early and reliable indicator of persistent or recurrent disease with important prognostic significance (1-4). Beside this, serum Tg is useful in the diagnosis of neonatal hypothyroidism. In hyperthyroid adults undetectable serum Tg suggests thyrotoxicosis factitia.

In conventional manual radioimmunoassys (RIAs) and radioactivity-free $\mathrm{Tg}$ assays, incubation steps of several hours are required and results are obtained only after up to $24 \mathrm{~h}$; with the Immulite Tg assay (Diagnostic Products Corporation, Los Angeles, CA, USA), now the first $\mathrm{Tg}$ assay implemented on a random access multichannel analyser is commercially available. With this luminescence-enhanced immunoenzymometric assay system results are obtained within 70 $\min$. The aim of our study was to investigate the analytical performance of this assay.

The most important performance goal for a Tg assay is a high precision at low serum $\mathrm{Tg}$ concentrations (4, 5). As detectable serum Tg usually results in further imaging work-up or even therapy $(6,7)$, this lowest concentration range is of far greater clinical significance for Tg assays than for most other tumor markers; therefore our evaluation was planned to focus particularly on the assay imprecision at the lowest concentration range.

\section{Materials and Methods}

Main assay characteristics of the Immulite $\mathrm{Tg}$ assay and the BRAHMS LUM Itest Tg assay (BRAHMS, Berlin, Germany) that was used for method comparisons are given in Table 1. The Immulite $\mathrm{Tg}$ assay is calibrated against the reference material CRM 457 (human Tg of glandular origin) provided by the European Community Bureau of References (Brussels, Belgium), whereas for the BRAHMS assay an in-house preparation is used. In the Immulite assay the only manual handling step is the transfer of samples from primary vessels into system assay cups and the positioning of test units together with the respective sample in a loading chain. Results can be uploaded to a laboratory data system. Chemiluminescence reaction is used as principle of detection; luminogenic substrate (Lumigen, adamantyldioxetane phosphate), reacts - catalyzed by antibodycoupled alkaline phosphatase - to form an unstable intermediate which gives sustained emission of light that is quantified by a photomultiplier. In contrast the BRAHMS LUM Itest Tg assay uses an acridinium ester as luminogen that only yields a single light emission. The latter assay is performed predominantly manually, though the luminogenic reaction and quantification is run in a semiautomated way by a chain luminometer (Berthold, Wildbad, Germany). In a previous study (unpublished data) a coefficient of variation of $20 \%$ was found at a Tg concentration of $1 \mathrm{ng} / \mathrm{ml}$ with this assay and therefore quantitative results are reported only above this concentration.

Assay studies were performed in a preroutine evaluation period (September to December 1997) and further evaluation data were obtained after beginning of the routine use of the 
Tab. 1 Technical characteristics of the DPC Immulite Tg assay and the BRAHMS LUM Itest Tg assay.

\begin{tabular}{|c|c|c|}
\hline & DPC Tg Immulite ${ }^{\circledR}$ assay & BRAHMS LUMItest ${ }^{\circledR}$ Tg assay \\
\hline Antibodies & $\begin{array}{l}\text { Monoclonal mouse-Ab (bead), luminescent- } \\
\text { substrate-labeled second polyclonal sheep-Ab }\end{array}$ & $\begin{array}{l}\text { Two monoclonal mouse-Ab (fixed on coated tube, } \\
\text { and luminescence labeled) }\end{array}$ \\
\hline Calibration & $\begin{array}{l}\text { Predefined master-calibration, two-point } \\
\text { adjustment in fourfold determination after } \\
14 \text { days } \\
\text { low adjustor: } \\
\varangle 0.2 \text { ng/ml, } 146447 \text { counts } \\
\text { high adjustor: } \\
26.9 \mathrm{ng} / \mathrm{ml}, 2815391 \text { counts }\end{array}$ & $\begin{array}{l}8 \text { standards in double determination } \\
(0.2-1000 \mathrm{ng} / \mathrm{ml}) \text { in each series }\end{array}$ \\
\hline Time to results & $\begin{array}{l}70 \mathrm{~min}, \text { random-access; start-up time approx. } \\
5 \mathrm{~min}\end{array}$ & approx. $24 \mathrm{~h}$ \\
\hline Sample volume & $50 \mu \mathrm{l}$ & $50 \mu \mathrm{l}$ \\
\hline Measuring range & $0.2-300 \mathrm{ng} / \mathrm{ml}$ & $0.2-1000 \mathrm{ng} / \mathrm{ml}$ \\
\hline Recovery test & $\begin{array}{l}200 \mu \mathrm{l} \text { serum }+10 \mu \mathrm{l} \text { recovery sample, } \\
100 \% \text { corresponds to }+45 \mathrm{ng} / \mathrm{ml} \mathrm{Tg} \\
\text { acceptable range } 70-130 \%\end{array}$ & $\begin{array}{l}50 \mu \mathrm{l} \text { serum }+10 \mu \mathrm{l} \text { Tg-recovery sample, } \\
100 \% \text { corresponds to }+100 \mathrm{ng} / \mathrm{ml} \mathrm{Tg} \text {; } \\
\text { acceptable range } 70-130 \%\end{array}$ \\
\hline
\end{tabular}

Immulite Tg assay from March until J une 1998. The evaluation and the routine use were performed by trained technicians according to the manufacturer's recommendations and the German guidelines for quality assurance.

\section{Imprecision}

For imprecision studies two human serum pools in a low and one pool in a high analyte concentration range were prepared, aliquoted after equilibration for $24 \mathrm{~h}$, and stored at $-20^{\circ} \mathrm{C}$ until analysis. The "high pool" contained $180 \mathrm{IU} / \mathrm{l}$ anti-Tg antibodies (DPC Anti-Tg Immulite assay, Diagnostic Products Corporation; normal < $100 \mathrm{IU} / \mathrm{l}$ ) whereas the low pools did not contain such antibodies. Interassay imprecision was determined by 21 independent measurements over 26 days; according to the manufacturer's recommendations a recalibration was performed after 14 days. Additionally, imprecision data from the two controls included in the reagent kit and a further human serum pool used for quality control during the routine use of the assay were assessed; these samples were stored at $4{ }^{\circ} \mathrm{C}$ for up to seven days between measurements and analyzed in 58 replicates. During this routine period of the study three kit lots of the Immulite Tg assay were used.

\section{Linearity}

In a linearity experiment a human serum pool with high $\mathrm{Tg}$ concentrations was diluted stepwise $(9+1$ to $1+9)$ with a "lowTg pool". The measurements were performed after equilibration of the diluted samples for one hour. The actual concentration of the high concentration sample was estimated by extrapolation from the low concentration sample and the concentration measured in the $5+5$ diluted sample. For each dilution step recoveries were calculated on the basis of observed and expected concentrations.

\section{Carry-over}

For a carry-over investigation a sample with a very high $\mathrm{Tg}$ concentration $(11400 \mathrm{ng} / \mathrm{ml})$ was repeatedly measured in direct sequence with a sample of a concentration below $1 \mathrm{ng} / \mathrm{ml}$.

\section{Interference}

Possible effects of typical interfering factors (bilirubin, hemolysis, uremia, and lipemia) were tested by spiking experiments: basal concentrations of Tg were measured in samples containing high amounts of interfering factors and a recovery test was performed in the same way as done routinely in patients' samples (Table 1). All samples were tested negative for anti-Tg antibodies.

\section{Cross-reactivity}

To test for cross-reactivity of the assay with thyroxine, two calibrators of a thyroxine immunoassay (ORTHO Vitros ECi; Neckargmünd, Germany, zero-calibrator and high-calibrator, thyroxine, $144 \mu \mathrm{g} / \mathrm{l}$ ) were analyzed for Tg with the Immulite assay.

\section{Anti-Tg antibodies}

To study the effect of anti-Tg antibodies, 56 sera of patients with thyroid carcinoma were screened using the DPC-Immulite Anti-Tg assay to obtain antibody-containing samples; in these samples Tg was measured with the Immulite Tg assay and for comparison with the BRAHMS Tg assay including recovery tests. Additionally, stepwise dilutions of the anti-Tg antibody containing high serum pool of the imprecision study with system diluent were prepared and measured with both assays; in this experiment the actual Tg concentration was calculated by extrapolation from the $1+1$ dilution with a normal anti-Tg antibody negative serum.

\section{Method comparison}

For a method comparison study, 383 consecutive serum samples of 303 patients with thyroid carcinoma were used that were routinely sent for monitoring of surgical and radioiodine therapy. Sera were analyzed within $24 \mathrm{~h}$ with the Immulite $\mathrm{Tg}$ assay and the BRAHMS LUM Itest Tg using a spiking recovery test in each sample. For analysis of the paired results of the two assays regression analysis according to Passing and Bablock (8) was performed and Kendall's tau and Pearson's coefficient of correlation were calculated. Additionally, a bias plot 
as described by Bland and Altman (9) was generated; in this analysis the percentage difference of the results of each sample obtained on the two systems is plotted against the respective mean of both methods.

\section{Interlaboratory survey}

During the study, the laboratory participated in an interlaboratory quality control programme involving two lyophilized samples which were measured both with the Immulite and the BRAHMS Tg assays (INSTAND Institute, Düsseldorf, Germany, survey 3/98).

\section{Results}

The results of the imprecision study are summarized in Table 2; since the coefficient of variation was about $10 \%$ at a $\mathrm{Tg}$ concentration of $0.8 \mathrm{ng} / \mathrm{ml}$ results equal to or below $0.5 \mathrm{ng} / \mathrm{ml}$ were assessed in the further evaluation. The dilution experiment confirmed linearity of the Immulite $\mathrm{Tg}$ assay over the whole measuring range $(0.2-300 \mathrm{ng} / \mathrm{ml})$ with recoveries between 94 and $110 \%$. No carry-over effect was observed at a Tg concentration of $11400 \mathrm{ng} / \mathrm{ml}$. The two highest Tg concentrations found during the evaluation were $256000 \mathrm{ng} / \mathrm{ml}$ and $76500 \mathrm{ng} / \mathrm{ml}$; in neither sample a high-dose hook effect was found. In the interference studies marked bilirubinemia was associated with an impaired recovery of spiked Tg (bilirubin $296 \mu \mathrm{mol} / \mathrm{l}$, 45\%; bilirubin 176 umol/l, $56 \%$ ).

Lipemic (triglycerides $10.7 \mathrm{mmol} / \mathrm{l}$ ), uremic (creatinine $698 \mu \mathrm{mol} / \mathrm{l}$ ), and hemolytic sera (free hemoglobin $40 \mu \mathrm{mol} / \mathrm{l}$ ) showed acceptable recoveries between 80 and $89 \%$.
In thyroxine assay calibrator preparations a Tg concentration of 0.65 and $0.55 \mathrm{ng} / \mathrm{ml}$ was found in the zeroand the high calibrator, respectively; a similar concentration is found in the Immulite Tg diluent.

The "high Tg pool" used for the imprecision study that contained $180 \mathrm{IU} / \mathrm{I}$ anti-Tg antibodies showed linearity of dilution both with the Immulite and the BRAHMS assay.

In the 57 sera screened for anti-Tg antibodies, significant antibody concentrations (>100 IU/I, manufacturer's reference range) were found in four; results of the Immulite and the BRAHMS Tg assay with the respective recovery of these samples are given in Table 3.

In the method comparison study using 383 sera of patients with thyroid carcinoma, the median Tg concentration found with the Immulite assay was 24.7 $\mathrm{ng} / \mathrm{ml}$, and $16.1 \mathrm{ng} / \mathrm{ml}$ with the BRAHMS assay. Thirtynine samples had Tg concentrations above the measuring range of the Immulite assay (>300 $\mathrm{ng} / \mathrm{ml}$ ) and 17 samples had to be diluted in the BRAHMS assay ( $>1000$ $\mathrm{ng} / \mathrm{ml})$. Values within the measuring range of either assay ( $n=180$ ) had a Kendall's tau coefficient of correlation of 0.890, and a Pearson's coefficient of correlation of 0.979 (Figure 1). Regression analysis according to Passing and Bablok yielded the following equation:

Tg Immulite $=1.6 \times \mathrm{Tg}$ BRAHMS $-0.1 \mathrm{ng} / \mathrm{ml}$

(95\% confidence interval: 1.52 to 1.66 for slope, and -0.60 to 0.62 for intercept). The bias plot according to Bland and Altman (Figure 2) disclosed a mean percentage difference (Immulite Tg - BRAHMS Tg) of 39.0\% (95\% confidence interval $33.0 \%$ to $45.0 \%$, standard deviation (SD) $41 \%$ ).

Tab. 2 Inter-assay imprecision of the DPC-Immulite Tg assay.

\begin{tabular}{|c|c|c|c|c|c|c|c|c|}
\hline \multirow[t]{2}{*}{ Sample } & \multirow[t]{2}{*}{$\mathrm{n}$} & \multirow{2}{*}{$\begin{array}{l}\text { Mean } \\
\text { concentration } \\
(\mathrm{ng} / \mathrm{ml})\end{array}$} & \multirow[t]{2}{*}{ SD } & \multirow[t]{2}{*}{$\mathrm{CV}$} & \multicolumn{2}{|c|}{ 1st half of the study } & \multicolumn{2}{|c|}{2 nd half of the study } \\
\hline & & & & & Mean & $\mathrm{CV}$ & Mean & $\mathrm{CV}$ \\
\hline Pool low I & 21 & 0.84 & 0.07 & $9.0 \%$ & 0.85 & 8.5 & 0.81 & 9.5 \\
\hline Pool low II & 21 & 1.4 & 0.15 & $10.9 \%$ & 1.3 & 11.2 & 1.4 & 10.6 \\
\hline Pool normal & 58 & 10.4 & 0.86 & $8.3 \%$ & 10.2 & 10.7 & 10.5 & 6.0 \\
\hline Pool high & 21 & 215 & 14.3 & $6.7 \%$ & 215 & 6.6 & 215 & 6.8 \\
\hline Control low & 58 & 9.8 & 0.79 & $8.1 \%$ & 9.6 & 9.9 & 10.0 & 6.5 \\
\hline Control high & 58 & 62.1 & 3.8 & $6.1 \%$ & 62.2 & 6.9 & 61.9 & 5.3 \\
\hline
\end{tabular}

Tab. 3 Comparative measurement and recovery of Tg in anti-Tg positive samples with the DPC-Immulite and the BRAHMS LUMItest Tg assay.

\begin{tabular}{llllll}
\hline Sample & $\begin{array}{l}\text { Anti-Tg } \\
\text { antibodies } \\
(\mathrm{U} / \mathrm{l})\end{array}$ & $\begin{array}{l}\mathrm{Tg} \\
\text { Immulite } \\
(\mathrm{ng} / \mathrm{ml})\end{array}$ & $\begin{array}{l}\mathrm{Tg} \\
\text { BRAHMS } \\
(\mathrm{ng} / \mathrm{ml})\end{array}$ & $\begin{array}{l}\text { Recovery } \\
\text { Immulite }\end{array}$ & $\begin{array}{l}\text { Recovery } \\
\text { BRAHMS }\end{array}$ \\
\hline 1 & 293 & 4.4 & 10.6 & $53 \%$ & $8.4 \%$ \\
$2^{*}$ & 180 & 226 & 218 & $50 \%$ & $75 \%$ \\
3 & 161 & 7.9 & 10.2 & $91 \%$ & $96 \%$ \\
4 & 129 & $<0.5$ & $<1$ & $94 \%$ & $96 \%$ \\
5 & 115 & 956 & 784 & $120 \%$ & $75 \%$ \\
\hline
\end{tabular}

\footnotetext{
* High pool of the imprecision study
} 


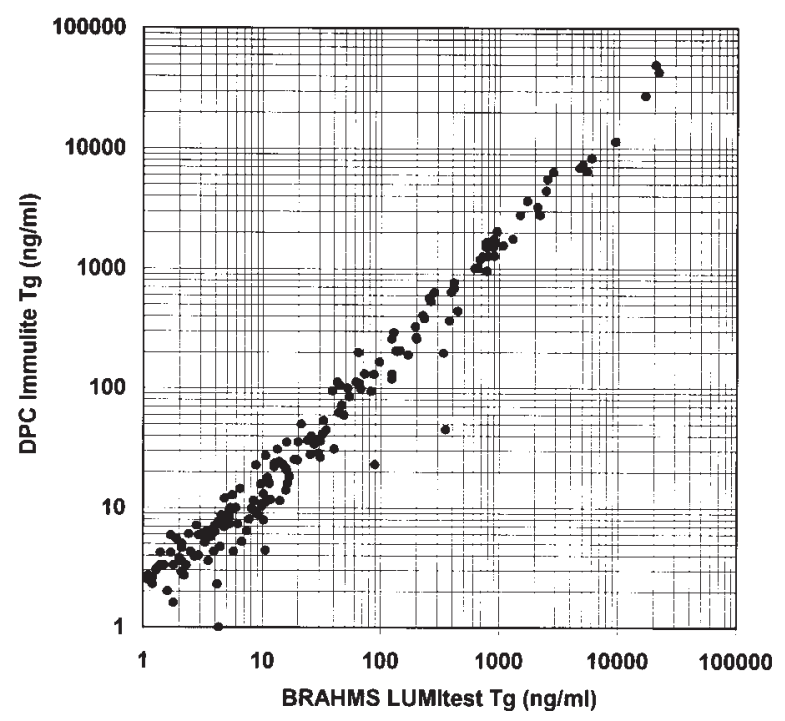

Fig. 1 Method comparison between the DPC-Immulite and the BRAHMS LUM Itest Tg assay in patients with differentiated thyroid carcinoma (note logarithmic scales; $n=180$; regression analysis according to Passing and Bablok Immulite $\mathrm{Tg}=1.6 \mathrm{x}$ BRAHMS Tg - $0.1 \mathrm{ng} / \mathrm{ml}$; Pearson's $r=0.979$ )
In 62 samples of the 383 sera of the method comparison study, Tg was below the assumed respective functional sensitivity in both assays (Immulite $\varangle 0.5 \mathrm{ng} / \mathrm{ml}$, BRAHMS $<1.0 \mathrm{ng} / \mathrm{ml}$ ). In 96 cases Immulite $\mathrm{Tg}$ was between 0.5 and $1.0 \mathrm{ng} / \mathrm{ml}$, whereas BRAHMS Tg was below $1.0 \mathrm{ng} / \mathrm{ml}$. Forty-seven samples had an Immulite Tg above $1.0 \mathrm{ng} / \mathrm{ml}$ and a BRAHMS Tg below $1.0 \mathrm{ng} / \mathrm{ml}$; the median Immulite Tg concentration of these samples was $1.7 \mathrm{ng} / \mathrm{ml}$ ranging up to $8 \mathrm{ng} / \mathrm{ml}$.

Comparative follow-up investigation was possible in 59 patients with thyroid carcinoma (two follow-up samples in 46 cases, three in 11, more than three in two cases). Agreement with respect to increase vs. decrease of serum $\mathrm{Tg}$ was found in 46 cases in which $\mathrm{Tg}$ was detected in both assays. In 13 follow-up investigations (see Table 4) Tg was not detectable with the BRAHMS assay in at least one sample. In patients no. 1 to no. 8 the first sample was drawn after thyroidectomy and before routinely performed radioiodine therapy; in these samples serum Tg was detected with the Immulite assay but not with the BRAHMS assay. In all cases in the respective subsequent sample drawn after destruction of residual thyroid tissue by radioiodine,

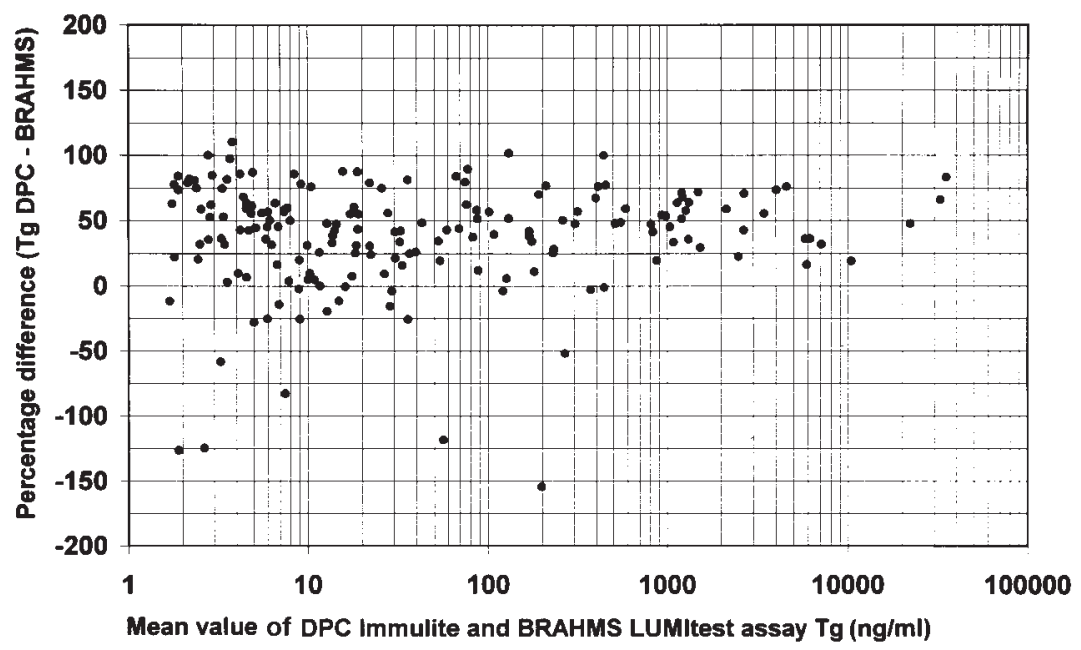

Fig. 2 Method comparison between the DPC-Immulite and the BRAHMS LUM Itest Tg assay in patients with differentiated thyroid carcinoma. Bias plot according to Altman and Bland (9) $(n=180)$.

Tab. 4 Tg concentrations during follow-up of patients with thyroid carcinoma who presented discordant results.

\begin{tabular}{rlllll}
\hline $\begin{array}{l}\text { Patient } \\
\#\end{array}$ & $\begin{array}{l}\text { Days } \\
\text { between } \\
\text { sampling }\end{array}$ & $\begin{array}{l}\text { Immulite } \\
\text { 1st result } \\
(\mathrm{ng} / \mathrm{ml})\end{array}$ & $\begin{array}{l}\text { Immulite } \\
\text { 2nd result } \\
(\mathrm{ng} / \mathrm{ml})\end{array}$ & $\begin{array}{l}\text { BRAHMS } \\
\text { 1st result } \\
(\mathrm{ng} / \mathrm{ml})\end{array}$ & $\begin{array}{l}\text { BRAHMS } \\
\text { 2nd result } \\
(\mathrm{ng} / \mathrm{ml})\end{array}$ \\
\hline 1 & 5 & 0.9 & 119 & $<1$ & 124 \\
2 & 5 & 2.7 & 4.2 & $<1$ & 1.7 \\
3 & 5 & 1.2 & 4.3 & $<1$ & 2.5 \\
4 & 5 & 2.4 & 8.8 & $<1$ & 9.0 \\
5 & 5 & 2.2 & 5.9 & $<1$ & 2.9 \\
6 & 5 & 2.2 & 7.7 & $<1$ & 4.6 \\
7 & 5 & 1.0 & 1.6 & $<1$ & 1.8 \\
8 & 5 & 1.4 & 4.3 & $<1$ & 5.7 \\
9 & 200 & 30.7 & 3.1 & 13.3 & $<1$ \\
10 & 7 & 1.0 & 1.4 & $<1$ & $<1$ \\
11 & 208 & 40.5 & 1.3 & $<1$ & $<1$ \\
12 & 5 & 0.7 & 2.3 & $<1$ & $<1$ \\
13 & 230 & 14.5 & 1.7 & 6.5 & \\
\hline
\end{tabular}


serum Tg was detected in both assays. In the patients no. 9 to no. 13 discordance was found with respect to the detection of $\mathrm{Tg}$, however, follow-up did not yet allow interpretation of the validity of either assay result.

The median recovery of all samples in the method comparison experiment $(n=383)$ was $95 \%$ (range 12 189 ) in the Immulite assay, and $91 \%$ (range 8-184) in the BRAHMS assay. In 49 cases a recovery below $70 \%$ was found with the Immulite assay (12.9\%), and in 19 cases with the BRAHMS assay (5\%). Forty-five samples had a recovery below $70 \%$ in the Immulite assay and with a recovery $>70 \%$ in the BRAHMS assay. The inverse pattern was found in five samples. Recoveries below $70 \%$ in both assays were found in only four cases.

In one patient with low percentage recovery in the spiking study with the Immulite assay (recovery 39 to $49 \%$ ) but a normal recovery in the BRAHMS assay (85 to $127 \%$ ), a comparative follow-up with five measurements over 8 months was possible. The results obtained using Immulite Tg were: (1) $3.6 \mathrm{ng} / \mathrm{ml}$; (2) 5.2 $\mathrm{ng} / \mathrm{ml}$; (3) $6.4 \mathrm{ng} / \mathrm{ml}$; (4) $4.3 \mathrm{ng} / \mathrm{ml}$; (5) $4.0 \mathrm{ng} / \mathrm{ml}$. The respective results obtained using BRAHMS assay were: (1) $3.5 \mathrm{ng} / \mathrm{ml}$; (2) $6.7 \mathrm{ng} / \mathrm{ml}$; (3) $7.4 \mathrm{ng} / \mathrm{ml}$; (4) $3.9 \mathrm{ng} / \mathrm{ml}$ (5) $2.9 \mathrm{ng} / \mathrm{ml}$; thus the follow-up was well comparable.

In an interlaboratory survey the results of both assays were within the respective assay target concentration ranges. The results were as follows:

Immulite Tg: sample A $1320 \mathrm{ng} / \mathrm{ml}$ observed, target concentration $1130 \mathrm{ng} / \mathrm{ml}$, acceptable range 621-1639 $\mathrm{ng} / \mathrm{ml}$ (mean concentration of $1208 \mathrm{ng} / \mathrm{ml}$ in 16 participating laboratories; CV 7.1\%). Sample B $174 \mathrm{ng} / \mathrm{ml}$ observed, target concentration 172, acceptable range 95-250 ng/ml (mean concentration of $170 \mathrm{ng} / \mathrm{ml}$ (CV 10.1) in all participants)

BRAHMS Tg: sample A $526 \mathrm{ng} / \mathrm{ml}$ observed, target concentration $533 \mathrm{ng} / \mathrm{ml}$, acceptable range 373-693 $\mathrm{ng} / \mathrm{ml}$ (mean concentration of $535 \mathrm{ng} / \mathrm{ml}$ in 28 participants; CV 6.8\%). Sample B $114 \mathrm{ng} / \mathrm{ml}$ observed, target concentration $114 \mathrm{ng} / \mathrm{ml}$ acceptable range 79-148 $\mathrm{ng} / \mathrm{ml}$ (mean concentration $114 \mathrm{ng} / \mathrm{ml}$ (CV 5.0\%) in all participants).

Handling and practicability of the Immulite immunoassay system in the daily routine proved very satisfactory; the highest possible throughput was 100 tests per hour. No technical problems were noticed during the 6 month period of the whole investigation.

\section{Discussion}

As highest reliability in the lowest concentration range is a key requirement for $\mathrm{Tg}$ determination, automation of a Tg assay is a particular analytical challenge; we therefore performed a minute evaluation of the first mechanized Tg assay, the DPC-Immulite Tg assay.

The imprecision studies disclosed satisfactory coefficients of variation in a human serum pool with a $\mathrm{Tg}$ concentration below $1 \mathrm{ng} / \mathrm{ml}$. Though imprecision of $\mathrm{Tg}$ assays at low analyte concentrations is known to be a critical issue (5), published data concerning commer- cial assays are limited; usually normal-concentration samples are used for imprecision studies $(10,11)$, the number of series is small (12) and some reported data lack details (13); different assay standardisations further hamper comparison of imprecision data. To our knowledge, reproducibility of Tg determination in the low concentration range described here using the Immulite Tg assay is superior to all published results of other commercial Tg assays.

Ensuring long-term stability of a Tg assay in the lowest concentration range over years represents an ongoing challenge for all manufacturers; so far no quality control material in the lowest concentration range is commercially available. Therefore, quality control in the routine use of a $\mathrm{Tg}$ assay should include human serum pools covering this range to verify long-term comparability of results.

The Immulite assay proved linear within the measuring range up to $300 \mathrm{ng} / \mathrm{ml}$. Compared to the BRAHMS assay (up to $1000 \mathrm{ng} / \mathrm{ml}$ ) this range is rather narrow. Consequently, dilution was necessary in more cases (Immulite $10 \%$, BRAHMS $4.4 \%$ of all samples). Even so, final results can be reported for a patient within one day with the Immulite assay. We were able to exclude a high-dose hook effect up to a concentration of 256000 $\mathrm{ng} / \mathrm{ml}$. In our experiments the assay did not show a carryover phenomenon or significant interference from lipemia, uremia and hemolysis, whereas in markedly icteric sera low Tg recovery was found; such samples should be diluted before analysis. No cross-reactivity with thyroxine was found; the Tg concentration found in the thyroxine assay calibrator as well as in the Tg system diluent obviously represents the Tg content of a stripped human serum matrix as the concentrations were equal in the low and the high thyroxine calibrator.

Anti-Tg antibody interference is a well recognized problem of Tg determination (14). In our experiments anti-Tg antibodies affected neither linearity nor precision of the Immulite $\mathrm{Tg}$ assay. In the comparative measurement of anti-Tg antibody containing samples with the Immulite and the BRAHMS assay, however, Tg concentrations found with the Immulite assay were beIow the BRAHMS results except for the sample with the lowest anti-Tg antibody concentration and the "high pool"; because of the considerable slope observed in the method comparison study, this observation suggests an effect of anti-Tg antibodies on the Immulite Tg assay resulting in lower results. However, serum $\mathrm{Tg}$ was detected in all patients in agreement with the BRAHMS assay.

In the Immulite assay, a higher percentage of samples with a recovery below $70 \%$ was found compared to the BRAHMS assay but the recommended conditions of the recovery test differ considerably between these two assays. In the recovery test as prescribed for the Immulite assay a lower amount of $\mathrm{Tg}$ is spiked to a larger sample volume; therefore this recovery test must generally be assumed to be more sensitive to analytical interferences. The comparative follow-up of one patient with low recovery results in the Immulite 
assay and normal recovery in the BRAHMS assay resulted in a good clinical agreement.

As no reference method for $\mathrm{Tg}$ determination is available, interpretation of the validity of $\mathrm{Tg}$ results is limited to the comparison with a clinically established method such as the BRAHMS assay. We found a slope of about $60 \%$ between the Immulite and the BRAHMS assay with higher values in the Immulite assay; the differences were even more pronounced using lyophilized interlaboratory survey material consistent with different matrix effects in such samples. The observed slope is explained by the use of different standard preparations in the two assays; the Immulite assay is calibrated with the international Tg standard (CRM 457 $(15,16))$, whereas the BRAHMS assay uses an in-house preparation. The use of the first certified standard preparation for Tg will probably improve the commutability of results between different Tg assays in the future (5, 17); generally patients' Tg results should always be reported together with the specification of the method used. If methods are changed in an institution new individual baseline values must be established for patients' follow-up. The bias plot according to Altman and Bland (9) shows that significantly lower Tg concentrations are obtained with the BRAHMS assay, particularly in the concentration range below $3 \mathrm{ng} / \mathrm{ml}$. This results in a poor commutability between the two assays. However, the short-term follow-up of patients no. 1 to 8 shown in Table 8 before and after postoperative radioiodine thyroablation gives strong evidence that Immulite $\mathrm{Tg}$ concentrations in the lowest concentration range are in fact valid: in these patients detectable serum $\mathrm{Tg}$ in both assays observed after radioiodine therapy obviously resulted from destruction of residual thyroid tissue. This implies that at the time of the first postoperative sampling thyroid tissue was indeed present, which was detected by the Immulite assay (concentrations $>0.5 \mathrm{ng} / \mathrm{ml}$ ) but not by the BRAHMS assay $(<1 \mathrm{ng} / \mathrm{ml})$. However, the actual long-term prognostic significance of concentrations between 0.5 and 1.0 $\mathrm{ng} / \mathrm{ml}$ Immulite $\mathrm{Tg}$ in patients treated for thyroid carcinoma is so far not defined.

We conclude that the automated Immulite Tg assay meets the requirements for routine clinical use; important advantages compared to the formerly used manual method are increased sensitivity and precision in the lowest concentration range, largely improved workflow, improved turnaround time and the use of an international standard preparation.

\section{References}

1. Ozata M, Suzuki S, Miyamoto T, Liu RT, Rierro-Renoy F, De Groot LJ . Serum thyroglobulin in the follow-up of patients with treated differentiated thyroid cancer. J Clin Endocrinol Metab 1994; 79:98-105.
2. Roelants V, De Nayer P, Bouckaert A, Beckers C. The predictive value of serum thyroglobulin in the follow-up of differentiated thyroid cancer. EurJ Nucl Med 1997; 24:722-7.

3. Schlumberger MJ . Papillary and follicular thyroid carcinoma. N Engl J Med 1997; 338:297-306.

4. Schlumberger M, Baudin E. Serum thyroglobulin determination in the follow-up of patients with differentiated thyroid carcinoma. Eur J Endocrinol 1998; 138:249-52.

5. Spencer CA, Takeuchi M, Kazarosyan M. Current status and performance goals for serum thyroglobulin assays. Clin Chem 1996; 42:164-73.

6. Mazzaferri EL. Treating high thyroglobulin with radioiodine: a magic bullet or a shot in the dark? ] Clin Endocrinol Metab 1995; 80:1485-7.

7. Pachucki 」, Burmeister LA. Evaluation and treatment of persistent thyroglobulinemia in patients with well-differentiated thyroid cancer. Eur J Endocrinol 1997; 137:254-61.

8. Passing H, BablokW. A new biometrical procedure for testing the equality of measurements from two different analytical methods. J Clin Chem Clin Biochem 1983; 21:709-20.

9. Bland J M, Altman DG. Statistical methods for assessing agreement between two methods of clinical measurement. Lancet 1986; i:307-10.

10. Dai J , Dent W, Atkinson J W, Cox J G, Dembrinski TC. Comparison of three immunoassay kits for serum thyroglobulin in patients with thyroid cancer. Clin Biochem 1996; 29:4461-5.

11. Knadler L, Panosian-Sahakian N, Unver E, El Shami AS. Highly sensitive thyroglobulin assay for the Immulite automated immunoassay analyzer. Clin Chem 1997; 43:S177.

12. Niederau CM, Uhl W. Enzymun-Test ${ }^{\circledR}$ TG: results from external evaluation. Anticancer Res 1997; 17:3141-4.

13. Marquet PY, Daver A, Sapin R, Bridgi B, Muratet J P, Hartmann $D J$, et al. Highly sensitive immunoradiometric assay for serum thyroglobulin with minimal interference from autoantibodies. Clin Chem 1996; 42:258-62.

14. Mariotti S, Barbesino G, Caturegli P, Marino M, Manetti L, Pacini $F$, et al. Assay of thyroglobulin in serum with thyroglobulin autoantibodies: an unobtainable goal? J Clin Endocrinol Metab 1995; 80:468-72.

15. Feldt-Rasmussen U, Profilis C, Colinet E, Schlumberger M, Black E. Purification and assessment of stability and homogeneity of human thyroglobulin reference material (CRM 457). Exp Clin Endocrinol 1994; 102:87-91.

16. Feldt-Rasmussen $U$, Schlumberger $M$. European interlaboratory comparison of serum thyroglobulin measurement. J Endocrinol Invest 1997; 11:175-81.

17. Zucchelli GC, Pilo A, Masini S, Prontera C, Ferdeghini M. Large between-laboratory variability of thyroglobulin immunoassays: data collected in a collaborative study. J Clin Ligand Assay 1996; 19:234-8.

Received 18 September 1998; accepted 3 December 1998

Corresponding author: Dr. med. Michael Vogeser, Institut für Klinische Chemie, Klinikum Grosshadern, D-81366 München, Germany

Tel.: +49 89 / 7095 - 3246, Fax: +49 89 / 7095 - 3240

Email: mvogeser@klch.med.uni-muenchen.de 